УдК 617.55-089.169-06:617.553-002,3-089.819

DOI 10.11603/2414-4533.2021.2.12300

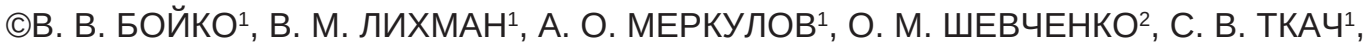
Д. О. МИРОШНИЧЕНКОㄹ, Є. О. БІЛОДІД', Н. В. БАЦМАН

ДУ "Інститут загальної та невідкладної хірургії імені В. Т. Зайцева НАМНУ"1

Харківський національний медичний університет²

\title{
Мінііназивні втручання у хворих із післяопераційними абсцесами черевної порожнини
}

\begin{abstract}
Мета роботи: поліпшити результати лікування хворих із післяопераційними абсцесами черевної порожнини 3 використанням мініінвазивних втручань.

Матеріали і методи. Проаналізовано результати лікування 52 хворих із післяопераційними абсцесами черевної порожнини. Середній вік хворих склав $(58 \pm 8,4)$ року, 41 (78,8 \%) хворий був віком до 60 років.

Результати досліджень та їх обговорення. Черезшкірні пункції під ультразвуковим або комбінованим контролем застосували у 20 (38,5\%) хворих із солітарними післяопераційними абсцесами. Всього таким хворим виконали 34 черезшкірні пункції. У 17 (85 \%) хворих доступи виконали під УЗ-контролем, без травмування внутрішніх органів, у одного (5 \%) хворого пункцію виконали через тканину печінки, у 2 (10 \%) - через плевральний синус. Усім хворим, незалежно від розміру абсцесу, його локалізації і тривалості процесу, пункцію вдалося виконати з першої спроби. У 3 (15 \%) хворих черезшкірна пункція була неефективна, тому 2 (10 \%) хворим виконали черезшкірне дренування, а одному (5 \%) - лапаротомію. Ускладнень після виконання черезшкірної пункції не спостерігали. Помер один (5 \%) хворий. Причина летального наслідку не пов’язана з ускладненням черезшкірного втручання. Смерть настала в результаті поліорганної недостатності на тлі розлитого перитоніту і сепсису. Тривалість лікування хворих з моменту першої пункції абсцесу до виписування зі стаціонару склала (11,2 $\pm 1,9)$ доби. Черезшкірні втручання у хворих із післяопераційними абсцесами черевної порожнини характеризуються високою клінічною ефективністю - 89,8 \% при дренуванні і 82,4 \% при застосуванні пункційних методик.
\end{abstract}

Ключові слова: абсцес черевної порожнини; пункція; дренування.

Постановка проблеми і аналіз останніх досліджень та публікацій. Питання діагностики та лікування післяопераційних абсцесів черевної порожнини на сьогодні залишаються актуальними для клінічної практики та охорони здоров'я [1]. У ряді випадків диференціальна діагностика при застосуванні різних методів дослідження становить труднощі і потребує проведення додаткових діагностичних прийомів для встановлення характеру патологічного процесу. Рання діагностика післяопераційних абсцесів черевної порожнини - запорука успішного лікування, профілактики післяопераційного перитоніту та інших ускладнень, зумовлених гнійно-септичним процесом [3, 4].

В останні роки лікування післяопераційних внутрішньочеревних абсцесів набуло характеру самостійного напрямку в абдомінальній хірургії. Однією з основних проблем цього напрямку стала розробка ефективних методів ранньої діагностики, своєчасного та адекватного їх хірургічного лікування [2].

Незважаючи на досягнення сучасної хірургії, частота виникнення післяопераційних внутрішньочеревних абсцесів $є$ стабільною й утримується на рівні від 0,6 до 1,9 \% [5], а летальність при них коливається від 13,7 до 61,4 \% [6]. Труднощі ранньої діагностики післяопераційних абсцесів черевної порожнини пов'язані з відсутністю патогномонічних симптомів, нерідко загальним тяжким станом хворого в перші дні після хірургічних утручань, застосуванням арсеналу сучасних антибактеріальних засобів та інтенсивної терапії, недостатньою розробкою скринінгу - методів ультразвукової та комп’ютерної діагностики [7].

Як основні етіологічні чинники формування гнійників черевної порожнини більшість авторів називає такі: гострий деструктивний апендицит $(0,8-2 \%)$ і холецистит $(0,2-2,5 \%)$, гостра кишкова непрохідність, дивертикуліт, гострий панкреатит, травми та операції на органах черевної порожнини, захворювання біліарного тракту, запальні захворювання кишечника $[7,8]$. Тяжкий стан хворого після операції найчастіше розглядають як наслідок операційної травми. На тлі інтенсивної терапії оцінка стану хворого, заснована виключно на інтерпретації клініко-лабораторних даних, неоднозначна, що може призвести до необгрунтованої релапаротомії [1]. Внаслідок цього виконане операційне втручання ще більше посилює тяжкий стан хворого, водночас пізня діагностика значно збільшує ризик несприятливого результату повторного втручання, спрямованого на його усунення [5]. Операція розтину внутрішньочеревного абсцесу - далеко не безпечне втручання, пов’язане з анатомічними 
особливостями розташування гнійників, яке тривалий період було причиною високого рівня смертність. Питання про найкращу операцію при даній патології зводиться фактично до питання про безпечний доступ [4].

Якщо абсцес являє собою добре відокремлену замкнуту порожнину, він може бути досить швидко усунений шляхом черезшкірного дренування [3, 2]. У тому випадку, якщо одна зі стінок абсцесу тісно прилягає до стінки порожнього органа або перебуває з нею в єдиному інфільтраті, може природним шляхом самоліквідуватися абсцес шляхом внутрішнього дренування у порожнистий орган із можливим повним одужанням [8]. Однак якщо в аналогічній ситуації здійснити черезшкірне дренування глибокого абсцесу, вміст абсцесу може спрямуватися шляхом найменшого опору, тобто через шкірну рану, захоплюючи за собою вміст кишки, у результаті чого утворюється глибока кишкова нориця, при якій проводять дренування норицевого каналу, а закриття останнього являє собою самостійну проблему [9, 4].

Перспективи хірургічного лікування ранніх післяопераційних внутрішньочеревних ускладнень пов'язані із застосуванням мініінвазивних методів, які поділяються на пункційні (черезшкірна пункція) та дренуючі (з встановленням дренажної трубки) [8, 6].

На вибір типу черезшкірного втручання впливає відстань до патологічного осередку, складність траєкторії проведення інструменту, передбачуваний характер вмісту [5]. При малих і середніх розмірах рідинних скупчень доцільніше проводити пункцію, при великих та гігантських - дренування $з$ встановленням іригаційно-аспіраційної системи [9, 2].

Мініінвазивний метод черезшкірного дренування під контролем УЗД та КТ стає стандартом лікування більшості внутрішньочеревних абсцесів $[7,1,4]$. Результати черезшкірного дренування багато в чому залежать від етіології абсцесу, однак спроба дренування показана при будь-якому гнійнику, до якого $є$ безпечна пункційна траєкторія. Залежно від розташування рідинно-кістозного утворення використовується пряма або коса траєкторія проведення пункційного пристрою. Використовували спеціальні голки різних фірм-виробників. Діаметр голок або дренажів вимірюється в міліметpax та позначається шкалою Шарьера в одиницях French (F), де I F = 0,33 мм [10]. Як і раніше не вирішене питання про спосіб дренування гнійних порожнин з використанням пасивного, активного або черезшкірного методів дренування. Все сказане визначає необхідність цього дослідження.
Матеріали і методи. Проаналізовано результатів лікування 52 хворих із післяопераційними абсцесами черевної порожнини, які перебували на лікуванні у клініці ДУ "Інститут загальної та невідкладної хірургії імені В. Т. Зайцева НАМНУ”. Середній вік хворих склав $(58 \pm 8,4)$ року, 41 (78,8 \%) хворий був віком до 60 років. Діагноз “післяопераційний абсцес черевної порожнини” встановили на підставі клінічної картини захворювання, даних лабораторних та інструментальних методів дослідження (УЗД, КТ), а також анамнезу захворювання. Всі хворі раніше були оперовані на органах черевної порожнини і малого таза.

Переважали хворі з доброякісними захворюваннями органів черевної порожнини - 75,7 \% випадків, 24,3 \% хворих мали злоякісні захворювання. Серед доброякісних захворювань частіше зустрічалася ЖКХ, хронічний холецистит (32,9 \%), серед злоякісних - рак шлунка (12,2 \%).

У 58,3 \% випадків абсцеси виявлено в термін 1-3 тижні з моменту операції. У 79,4 \% хворих післяопераційні абсцеси були поодинокими, у 20,6 \% - множинними. Розташовувалися вони у всіх відділах черевної порожнини. Найчастіше абсцеси зустрічалися в підпечінковому та піддіафрагмальному просторах, а також в печінці.

У 8 (15,4 \%) хворих мало місце сполучення порожнини абсцесу з порожнинними органами черевної порожнини: у 7 (13,4 \%) - 3 жовчовивідною системою, у 3 (5,7 \%) - $з$ кишечником (з клубовою та поперечно-ободовою кишкою). Нориця 3 жовчовивідної системою частіше зустрічалась при локалізації абсцесу в підпечінковому просторі та печінці.

Показаннями для черезшкірної пункції вважали: розмір абсцесу до 4-5 см або складне топографо-анатомічне розташування, що не дало можливості виконати черезшкірне дренування. Показаннями до черезшкірного дренування вважали розмір абсцесу більше 5-6 см, а також неефективність пункції. Такий розподіл зумовлений тим, що при дренуванні використовували поліетиленові дренажі розміром 12 F з системою фіксації за рахунок згортання дистального кінця дренажу в кільце діаметром 3 см.

Лікувальну пункцію виконали 19 (36,5 \%) хворим із поодинокими абсцесами при розмірі абсцесу до 4-5 см та в одного хворого при абсцесі розміром 9 см. Черезшкірне дренування одним дренажем виконали 21 (40,3 \%) хворому з одиничним абсцесом при розмірі абсцесу від 6 до 12 см, та 6 (11,5 \%) хворим з абсцесами розміром менше 4-5 см після неефективної черезшкірної пункції. У 5 (9,6 \%) хворих з абсцесами більше 10-12 см 
дренування виконали двома дренажами з подальшим використанням аспіраційно-промивної системи.

Результати досліджень та їх обговорення. Черезшкірні пункції під ультразвуковим або поєднаним контролем застосували у 20 (38,5 \%) хворих із поодинокими післяопераційними абсцесами. Всього у цих хворих виконали 34 черезшкірні пункції. Доступи у 17 (85 \%) хворих були позаорганними, в одного (5 \%) хворого пункцію виконали через тканину печінки, у двох (10 \%) - через плевральний синус. Усім хворим незалежно від розміру абсцесу, його локалізації та тривалості процесу пункцію вдалося виконати з першої спроби.

Наявність ехомаркерів на стовбурі голки забезпечило хорошу ультразвукову візуалізацію голки, дало можливість чітко контролювати ії положення в тканинах і сприяло високій точності потрапляння в порожнину абсцесу, уникаючи травми внутрішніх органів і кровоносних судин.

Проведення голки до протилежної стінки абсцесу забезпечило її стійке положення в порожнині та дало можливість у всіх хворих уникнути передчасного виходу голки з абсцесу під час аспірації та санації.

У 51,8 \% хворих пункцію абсцесу здійснили одноразово. Після аспірації гною, санації порожнини абсцесу та введення діоксидину у обсязі 5 мл спостерігали виражений позитивний ефект.

За даними контрольного УЗД, виконаного на наступний день, у 75,8 \% хворих порожнина абсцесу не визначалась, а у 24,2 \% - була в межах обсягу залишеного антибактеріального препарату. У наступні дні спостерігали зменшення залишкової порожнини аж до повного ії̈ зникнення.

За даними термометрії, ввечері, у день втручання, температура тіла не перевищувала $37,6^{\circ} \mathrm{C}$. На наступний ранок і в подальшому температура тіла була в межах норми.

За даними загального аналізу крові на 1-3 доби відзначили зниження лейкоцитозу в середньому на $2,7 \pm 1,3 \times 10 \%$ млл. Також відбулося зменшення відносної кількості паличкоядерних та сегментоядерних лейкоцитів. На 3-5 доби кількість лейкоцитів зни-

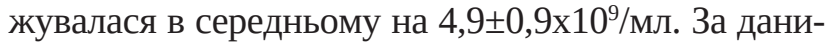
ми термометрії, ввечері після першої пункції температура тіла знизилася, проте перевищувала $37,7^{\circ} \mathrm{C}$. На наступний ранок і ввечері наступного дня температура тіла зберігалася в межах 37,9-38, $1^{\circ} \mathrm{C}$. Після повторної пункції в цих хворих спостерігали виражений позитивний ефект: зникли клінічні прояви гнійної інтоксикації, температура тіла не перевищувала показника норми. Залишкова порожнина, за даними контрольного УЗД, стабілізувалася в обсязі залишеного антибактеріального препарату, а в наступні дні зменшувалася аж до повного зникнення. За даними загального аналізу крові, після першої пункції спостерігали деяке збільшення лейкоцитозу, у середньому на 2,8 $\pm 1,2 \times 10 \%$ /мл, проте кількість паличкоядерних лейкоцитів знижувалася. Після повторної пункції кількість лейкоцитів знижувалася до нормальних значень.

При повторній пункції 3 хворим виконали контрастування порожнини абсцесу. Показанням послугували наявність домішок жовчі в гнійному відокремлювані (2 хворі) і розмір залишкової порожнини, що перевищувала початковий розмір абсцесу (1 хворий). За даними фістулографії, у 2 хворих із підпечінковими абсцесами виявили норицю 3 жовчовивідною системою, а у одного хворого з поддіафрагмальним абсцесом - неправильну форму із затіканнями. Отримані дані були показанням для виконання черезшкірного дренування. Контрастне дослідження під час першої пункції було виконане одному хворому з підпечінковим абсцесом. Показаннями була наявність домішок жовчі в гнійному відокремлюваному. При контрастуванні визначалися жовчні протоки до рівня загальної жовчної без контрастування дванадцятипалої кишки, що слугувало показанням до виконання лапаротомії.

У 3 (15 \%) хворих черезшкірна пункція була неефективною, в зв'язку з чим 2 (10 \%) хворим виконали черезшкірне дренування, а одному (5 \%) - лапаротомію. Ускладнень після черезшкірної пункції не було. Помер 1 (5 \%) хворий. Причина летального результату не пов'язана з ускладненням черезшкірного втручання. Смерть настала через поліорганну недостатність на тлі розлитого перитоніту і сепсису. Тривалість лікування хворих від моменту першої пункції абсцесу до виписування зі стаціонару склала $(11,2 \pm 1,9)$ доби.

Таким чином, при лікуванні хворих із поодинокими післяопераційними абсцесами черевної порожнини з застосуванням черезшкірної пункції отримано такі результати: ефективність лікування склала - 82,4 \%, неефективність - 12,6 \% і була зумовлена неадекватною санацією через неправильну форму абсцесу з наявністю затікань та наявністю нориці з жовчовивідної системою. Ускладнень не було. Летальність склала 5 \% (1 хворий). У 32 хворих $з$ поодинокими післяопераційними абсцесами черевної порожнини виконали 47 черезшкірних дренувань, в тому числі у 42 - як первинне втручання, а у 5 - після неефективної черезшкірної пункції. Доступ у 86,8 \% хворих був позаорганним, у 5,4 \% - трансплевральним, у 7,8 \% - че- 


\section{З ДОСВІДУ РОБОТИ}

резпечінковим. Дренування одним дренажем виконали 82,6 \% хворих, двома дренажами - 17,4 \% хворих. Усім хворим дренування вдалося виконати з першої спроби, незалежно від розміру та локалізації абсцесу. Використання дренажів діаметром 12F з механізмом фіксації забезпечувало стабільність положення дренажу в порожнині абсцесу і запобігало його дислокації.

У 27,5 \% хворих спостерігали сполучення порожнини абсцесу з порожнистими органами черевної порожнини: у 22,2 \% - 3 жовчовивідною системою, у 3,9 \% - 3 кишечником (з клубовою та поперечно-ободовою кишкою).

Наявність сполучення з жовчовивідною системою не вважали показанням до виконання лапаротомії. Фістулографію у даної категорії хворих виконували двічі на тиждень. У 6 хворих з жовчними норицями були відсутні порушення прохідності жовчних протоків. У всіх цих хворих нориці закрилися самостійно і не потребували додаткового операційого втручання. У двох хворих, які мали норицю з кишечником, черезшкірне дренування було успішним, кишкові нориці закрили. У 7 (12,4 \%) хворих, що мали розміри абсцесів більше 10-12 см, дренування виконали одномоментно двома дренажами, ускладнень при цьому не отримали. У всіх хворих (навіть при великому розмірі післяопераційного абсцесу) черезшкірне лікування було ефективним.

У 2 (6,2 \%) хворих із поодинокими післяопераційними абсцесами спостерігали ускладнення. Одне (3,1 \%) з них було інфекційним. У хворого після трансплеврального дренування абсцесу лівого піддіафрагмального простору розвинувся гнійний плеврит. У другого хворого з абсцесом лівого піддіафрагмального простору на 12 добу дренування відбулася повна дислокація дренажу. Причиною стала випадкова тракція дренажу хворим. Через сім днів після дислокації хворий у задовільному стані був виписаний на амбулаторне лікування.

У зв'язку з неефективністю черезшкірного дренування 3 (9,4 \%) хворим виконали лапарото- мію. У двох хворих причиною неефективності була нориця з жовчовивідною системою в поєднанні з порушенням прохідності загальної жовчної протоки. В одного хворого з післяопераційним абсцесом печінки причиною неефективності стало неадекватне дренування за рахунок наявності секвестру. Летальних випадків у даній групі хворих не було. Тривалість лікування від моменту дренування абсцесу до виписування зі стаціонару склала $(19,6 \pm 1,8)$ доби, тривалість дренування абсцесу - $(18,1 \pm 1,4)$ доби. Таким чином, у хворих з поодинокими післяопераційними абсцесами після черезшкірного дренування отримано такі результати: ефективність лікування склала 89,8 \%; неефективність - 4 \%; ускладнення - 6,2 \%; операційні втручання $з$ приводу ускладнень та летальність були відсутні.

Висновки. Черезшкірні втручання у хворих із післяопераційними абсцесами черевної порожнини характеризуються високою клінічною ефективністю - 89,8 \% при дренуванні та 82,4 \% - при застосуванні пункційних методик. Основними причинами неефективності черезшкірних втручань при пункціях є неадекватна санація через неправильну форму абсцесу з наявністю затікань та сполучення абсцесу з жовчними протоками, а при дренуванні сполучення абсцесу з жовчовивідною системою в поєднанні з порушенням пасажу жовчі.

При порівнянні результатів застосування черезшкірних втручань у хворих з післяопераційними абсцесами можна відзначити, що черезшкірне дренування, виконане за допомогою УЗ-наведення, характеризується більшою клінічною ефективністю, ніж черезшкірна пункція. Частота ускладнень при дренуванні (6,2%) була достовірно вище, ніж при пункціях (0 \%). Загальна летальність була вищою при черезшкірній пункції, проте летальність від ускладнень черезшкірного втручання була відсутня в обох групах. Тривалість лікування при дренуванні була у 2 рази більше ( $<0,01)$, ніж при пункції.

\section{СПИСОК ЛІТЕРАТУРИ}

1. Вайнер Ю. С. Тонкокишечный анастомоз в условиях перитонита : диссертация (экспериментально-анатомическое исследование). - Новосибирск, 2018. - 138 с.

2. Abdel-Kader S. Complicated intra-abdominal infections: a prospective validation study of the WSES Sepsis Severity Score / S. Abdel-Kader, M. Sartelli, F. M. Abu-Zidan // Singapore Med. J. - 2019. - Vol. 60 (6). - P. 317-321.

3. Азаренок А. С. Некоторые аспекты рациональной периоперационной антибиотикопрофилактики в отделениях хи-

рургического профиля (обзор) / А. С. Азаренок, Е. И. Михайлова // Вопросы организации и информатизации здравоохранения. - 2019. - 1 (98). - С. 64-68.

4. Index of Mannheim and mortality in sepsis abdominal / L. G. González-Pérez, Y. Sánchez-Delgado, A. R. GodínezVidal [et al.] // Cirugia y Ciruganos. - 2018. - Vol. 86 (5). P. 423-427.

5. Абдоминальная инфекция и сепсис: национальные клинические рекомендации / Б. Р. Гельфанд, А. И. Кириенко, 
М. Д. Дибиров [и др.] // Инфекции в хирургии. - 2017. - 15 (3-4). С. 2-27.

6. Risk factors for postoperative intra-abdominal abscess after laparoscopic appendectomy: Analysis for consecutive 1,817 experiences / J. Cho, I. Park, D. Lee [et al.] // Digestive Surgery. - 2015. - Vol. 32 (5). - P. 375-381.

7. Брусина Е. Б. Инфекции, связанные с оказанием медицинской помощи в хирургии: тенденции и перспективы профилактики / Е. Б. Брусина, О. В. Ковалишева, А. М. Цигельник // Эпидемиология и вакцинопрофилактика. - 2017. - 4 (95). - С. 73-80.

\section{REFERENCES}

1. Vayner, Yu.S. (2018). Tonkokishechnyy anastomoz v usloviyakh peritonita [Small bowel anastomosis in conditions of peritonitis]. Thesis. Novosibirsk [in Russian].

2. Abdel-Kader, S., Sartelli, M., \& Abu-Zidan, F.M. (2019). Complicated intra-abdominal infections: a prospective validation study of the WSES Sepsis Severity Score. Singapore Med. J., 60 (6), 317-321.

3. Azarenok, A.S., \& Mihaylova, E.I. (2019). Nekotorye aspekty ratsionalnoy perioperatsionnoy antibiotikoprofilaktiki v otdeleniyah hirurgicheskogo profilya (obzor) [Some aspects of rational perioperative antibiotic prophylaxis in surgical departments (review)]. Voprosy organizatsii i informatizatsii zdravoohraneniya - Issues of Organization and Informatization of Health Care, 1 (98), 64-68 [in Russian].

4. González-Pérez, L.G., Sánchez-Delgado, Y., Godínez-Vidal, A.R., Cruz-Manzano, J.F., Gutiérrez-Uvalle, G.E., \& Gracida-Mancilla, N.I. (2018). Index of Mannheim and mortality in sepsis abdominal. Cirugia y Ciruganos, 86 (5), 423-427.

5. Gelfand, B.R., Kirienko, A.I., \& Dibirov, M.D. (2017). Abdominalnaya infektsiya i sepsis: natsionalnye klinicheskie rekomendatsii [Abdominal infection and sepsis: national clinical guidelines]. Infektsii $v$ hirurgii - Infections in Surgery, 15 (3-4), 2-27 [in Russian].
8. Затевахин И. И. Неотложная абдоминальная хирургия (практическое руководство для практикующего врача) / И. И. Затевахин, А. И. Кириенко, А. В. Сажина. - Москва : МИА, 2018. - 488 с.

9. Гостищев В. К. Клиническая оперативная гнойная хирургия / В. К. Гостищев. - Москва : ГЭОТАР-Медиа, 2016. -441 c.

10. Лікувально-діагностична тактика при рідинно-кістозних утвореннях підшлункової залози / В. В. Бойко, В. М. Лихман, О. М. Шевченко // Клінічна хірургія. - 2019. - 3. - С. 3-6.

6. Cho, J., Park, I., Lee, D., Sung, K., Baek, J., \& Lee, J. (2015). Risk factors for postoperative intra-abdominal abscess after laparoscopic appendectomy: Analysis for consecutive 1,817 experiences. Digestive Surgery, 32 (5), 375-381.

7. Brusina, E.B., Kovalisheva, O.V., \& Tsigelnik, A.M. (2017). Infektsii, svyazannye s okazaniem meditsinskoy pomoshchi $\mathrm{v}$ hirurgii: tendentsii i perspektivy profilaktiki [Infections associated with the provision of medical care in surgery: trends and prospects for prevention]. Epidemiologiya $i$ vaktsinoprofilaktika Epidemiology and Vaccine Prevention, 4 (95), 73-80 [in Russian]. 8. Zatevahin, I.I., Kirienko, A.I., \& Sazhina, A.V. (2018). Neotlozhnaya abdominalnaya hirurgiya (prakticheskoe rukovodstvo dlya praktikuyushchego vracha) [Emergency abdominal surgery (A practical guide for the practitioner)]. Moscow: MIA [in Rusian]. 9. Gostishchev, V.K. (2016). Klinicheskaya operativnaya gnoynaya hirurgiya [Clinical operative purulent surgery]. Moscow: GEOTAR-Media [in Russian].

10. Boyko, V.V., Lihman, V.M., Shevchenko, O.M., Merkulov, A.O., \& Polikov, G.O. (2019). Likuvalno-diahnostychna taktyka pry ridynno-kistoznykh utvorenniakh pidshlunkovoi zalozy [Therapeutic and diagnostic tactics for fluid-cystic formations of the pancreas]. Klinichna khirurhiia - Clinical Surgery, 3, 3-6 [in Ukrainian].

Отримано 22.02.2021

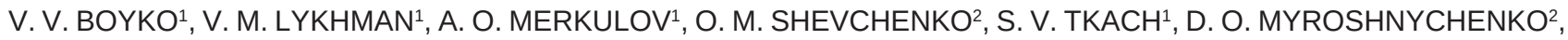
E. O. BILODID ${ }^{1}$ N. V. BATSMAN ${ }^{1}$

V. Zaitsev Institute of General and Emergency Surgery of the National Academy of Medical Sciences of Ukraine ${ }^{1}$ Kharkiv National Medical University²

\section{MINIMALLY INVASIVE INTERVENTIONS IN PATIENTS WITH POSTOPERATIVE ABDOMINAL ABSCESSES}

The aim of the work: to improve the results of treatment of patients with postoperative abscesses of the abdominal cavity using minimally invasive interventions.

Materials and Methods. The results of treatment of 52 patients with postoperative abscesses of the abdominal cavity were analyzed.

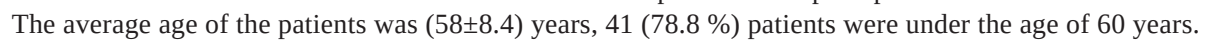

Results and Discussion. Percutaneous punctures under ultrasound or combined control were used in 20 (38.5 \%) patients with solitary postoperative abscesses. In total, 34 percutaneous punctures were performed in these patients. Accesses in 17 (85 \%) patients were under ultrasound navigation, without injury to internal organs, in one (5\%) patient, puncture was performed through the liver tissue, in two $(10 \%)$ - through the pleural sinus. All patients, regardless of the size of the abscess, its localization and the duration of the process, 
the puncture was performed on the first attempt. In $3(15 \%)$ patients, percutaneous puncture was ineffective, and therefore 2 (10 \%) patients underwent percutaneous drainage, and one (5\%) - laparotomy. There were no complications after percutaneous puncture. 1 ( $5 \%$ ) patient died. The cause of death is not related to the complication of percutaneous intervention. Death occurred as a result of multiple organ failure against the background of diffuse peritonitis and sepsis. The duration of treatment of patients from the moment of the first puncture of the abscess to discharge from the hospital was (11.2 \pm 1.9$)$ days. Percutaneous interventions in patients with postoperative abdominal abscesses are characterized by high clinical efficacy $-89.8 \%$ for drainage and $82.4 \%$ for puncture techniques.

Key words: abdominal abscess; puncture; drainage.

В. В. БОЙКО Е. А. БЕЛОДЕД ${ }^{1}$, Н. В. БАЦМАН ${ }^{1}$

ГУ “Институт общей и неотложной хирургии имени В. Т. Зайцева"1

Харьковский национальный медицинский университет ${ }^{2}$

\title{
МИНИИНВАЗИВНЫЕ ВМЕІІАТЕЛЬСТВА У БОЛЬНЫХ С ПОС.ЛЕОПЕРАЦИОННЫМИ АБСЦЕССАМИ БРЮШНОЙ ПОЛОСТИ
}

\begin{abstract}
Цель работы: улучшить результаты лечения больных с послеоперационными абсцессами брюшной полости с использованием миниинвазивных вмешательств.

Материалы и методы. Проанализированы результаты лечения 52 больных с послеоперационными абсцессами брюшной полости. Средний возраст больных составил $(58 \pm 8,4)$ года, 41 (78,8 \%) больной был в возрасте до 60 лет.

Результаты исследований и их обсуждение. Чрескожные пункции под ультразвуковым или комбинированным контролем применили у 20 (38,5 \%) больных с солитарными послеоперационными абсцессами. Всего в этих больных выполнили 34 чрескожных пункции. Доступы в 17 (85 \%) больных были под УЗ- навигацией, без травмирования внутренних органов, у одного (5 \%) больного пункцию выполнили через ткань печени, в двух (10 \%) - через плевральный синус. Всем больным независимо от размера абсцесса, его локализации и продолжительности процесса пункцию удалось выполнить с первой попытки.

У 3 (15 \%) больных чрескожная пункция была неэффективной, в связи с чем 2 (10 \%) больным выполнили чрескожное дренирование, а одному (5 \%) - лапаротомию. Осложнений после чрескожной пункции не было. Умер 1 (5 \%) больной. Причина летального исхода не связана с осложнением чрескожного вмешательства. Смерть наступила в результате полиорганной недостаточности на фоне разлитого перитонита и сепсиса. Продолжительность лечения больных с момента первой пункции абсцесса до выписки из стационара составила $(11,2 \pm 1,9)$ сутки. Чрескожные вмешательства у больных с послеоперационными абсцессами брюшной полости характеризуются высокой клинической эффективностью - 89,8 \% при дренировании и 82,4 \% - при применении пункционных методик.
\end{abstract}

Ключевые слова: абсцесс брюшной полости; пункция; дренирование. 